\title{
Analgesic and antidepressant activities of Brassica rapa subspecies chinensis (L.) Hanelt on Swiss-albino mice model
}

\author{
Rahman MS ${ }^{1}$, Jahan $\mathrm{N}^{2}$, Rahman $\mathrm{SMA}^{2}$, Rashid MA ${ }^{1}$ \\ ${ }^{1}$ Department of Pharmaceutical Chemistry, Faculty of Pharmacy, University of Dhaka, Dhaka-1000, \\ Bangladesh. ${ }^{2}$ Department of Pharmacy, State University of Bangladesh, Dhaka-1205, Bangladesh \\ Email: rashidma@du.ac.bd
}

\begin{abstract}
Bangladesh being a subtropical country provides varieties of herbs and vegetables. Brassica is a broad genus available in Bangladesh and it encompasses a lot of nutritive herbs. Among these, Brassica rapa subspecies chinensis (L.) Hanelt (Family-Brassicaceae) is popular in many parts of the world. In the quest of medicinal property, this plant was investigated here for observing analgesic and antidepressant activities in Swiss-albino mice model. The herb was extracted well with methanol and then assayed by acetic acid-induced writhing and tail immersion methods for analgesic action. Besides, thiopental sodium induced sleeping time test, tail suspension test and forced swim test were conducted for the evaluation of its antidepressant activity. The plant extract was orally administered to the mice at 200 and $400 \mathrm{mg} / \mathrm{kg}$ body weight and it exhibited significant analgesic and antidepressant activities in compare to the controlled groups. This is the first time comprehensive report for analgesic and antidepressant activities of this plant.
\end{abstract}

Keywords: Brassica rapa subspecies chinensis, Analgesic, Antidepressant, Acetic Acid, Heat Stimuli, Forced Swimming Test, Tail Suspension Test

\section{Introduction}

Plants are the natural reservoir of medicinal components, which are known as bioactive secondary metabolites. They are very valuable for providing lead molecules for drug discovery. Screening of the plants focusing on bioactivities is essential to find out disease specific drug candidates. ${ }^{1-3}$

Pain is always associated with injury and some disease states. It may be very fatal for some patients. So, the management of pain is important to ease it. Besides, depressive disorders are seen among large number of people. Relive from the depressive symptoms are essential to maintain a normal life. Many drugs are currently available but they are not free of side effects. In this regard, plants can be screened to find out new safer analgesic and antidepressant drugs. ${ }^{4-7}$ Bangladesh as a natural reservoir of numerous plants has a greater opportunity to screen out the plants for their analgesic and antidepressant drugs.

Brassica rapa subsp. chinensis (Bengali name: Bati shak) is a member of Brassicaceae family. It contains light green and thin leaves. At the base of the leaf petioles, white-fleshed roots are available. The flowers remain as cluster on the top of the raceme. Many subspecies of B. rapa are popular as vegetable herb containing many nutrients, vitamins, minerals and antioxidants. ${ }^{8,9}$ Previous chemical studies of Brassica genus reported the isolation of phenolics and organic acids. ${ }^{10-13}$

As a part of our continuing studies on medicinal plants of Bangladesh, ${ }^{14-18}$ our aim was to screen $B$. rapa subspecies chinensis for primary analgesic and antidepressant activities. This is the first time report regarding these bioassays of this plant and it might be useful for inspiring bioactivity guided isolation of compounds from this herb. Nutraceutical and herbal drug producers might be benefited from this study for their product development by using this plant.

\section{Materials and Methods}

Drugs and chemicals: Acetic acid (Merck, Germany), normal saline solution (Beximco Infusion Limited, Bangladesh), tween-80 (BDH Chemicals, UK), diclofenac sodium (Square Pharmaceuticals Limited, Bangladesh), morphine sulphate (Gonoshasthaya Pharmaceuticals Limited, Bangladesh), thiopental sodium 
(Beximco Pharmaceuticals Limited, Bangladesh), Fluoxetine (Square Pharmaceuticals Limited, Bangladesh) and diazepam (Square Pharmaceuticals Limited, Bangladesh) were used in this investigation.

Plant materials: The whole plant of $B$. rapa subspecies chinensis was collected on June, 2013 from Gazipur, Bangladesh and a voucher specimen (DACB Accession No: 39457) has been deposited at Bangladesh National Herbarium, Mirpur, Dhaka for future reference. The collected plant was dried for a week and ground into a coarse powder. The powder was stored in an airtight container and kept in a cool, dark and dry place until experiment commenced.

Preparation of the methanol extract of the plant: About $500 \mathrm{~g}$ of powdered material of the plant was taken in clean, flat bottomed glass container and soaked in $1 \mathrm{~L}$ of methanol. It was then sealed and kept for a period of 7 days accompanying occasional shaking and stirring. The whole mixture was filtered through a clean, cotton bed followed by Whatman filter paper number 1 (Bibby RE200, Sterilin Limited, UK). The filtrate obtained was evaporated by using a rotary evaporator to afford a gummy concentrate, which were designated as crude methanol extract. The extract was transferred to a closed container separately for further use.

Animals: Swiss-albino mice of either sex aged 45 weeks, average weight 20-25 g were used for the experiment. They were kept in standard environmental condition (at $24.0 \pm 1{ }^{\circ} \mathrm{C}$ temperature and 55-65\% relative humidity and 12 hour light/12 hour dark cycle) for a week for acclimation after their purchase and fed with rodent food purchased from International Centre for Diarrheal Diseases and Research, Bangladesh (ICDDR,B) and water ad libitum. Each group in all experiments contained three mice.

Acetic acid-induced writhing method for peripheral analgesic assay: The peripheral analgesic activity was evaluated in mice using acetic acid induced writhing method. ${ }^{19-21}$ Intraperitoneal acetic acid administration produces pain which causes subsequent writhing. Prior administration of analgesic agent reduces the writhing. In this experiment, the plant extract
(200 and $400 \mathrm{mg} / \mathrm{kg}$ body weight), diclofenac sodium ( $1 \mathrm{mg} / \mathrm{kg}$ body weight; positive control) and vehicles were administered orally to the overnight fast mice. Thirty minutes later, intraperitoneal administration of $0.7 \%(\mathrm{v} / \mathrm{v})$ acetic acid solution (10 ml/kg body weight) was conducted. Then the animals were placed on an observation table and the writhing number was counted.

Tail immersion technique for central analgesic assay: The tail immersion method is an alternative method to evaluate central analgesic activity. ${ }^{22,23}$ Here, the painful thermal stimulus in mice was generated by dipping the tip of the tail in hot water. In short, the mice selected for this study were divided into 4 groups having 3 per cage. Test groups were pre-treated with oral administration of 200 and $400 \mathrm{mg} / \mathrm{kg}$ body weight of the methanolic crude extract, while $10 \mathrm{ml} / \mathrm{kg}$ body weight distilled water orally and $2 \mathrm{mg} / \mathrm{kg}$ body weight of morphine (subcutaneously) were administered to control and standard drug treated groups, respectively. After 30 minutes, each mouse was restrained in horizontal cylinders leaving the tail hanging freely and immersed in a water bath maintained at $55 \pm 1^{\circ} \mathrm{C}$. The time taken for the mouse to remove its tail out of the water was recorded. This latency was again evaluated after 60 and 90 minutes.

Antidepressant assay through thiopental sodium induced sleeping time test: In this experiment ${ }^{24}$, the 12 mice were equally divided into 4 groups. The test groups were orally administered with test samples prepared with normal saline water and tween- 80 at doses of 200 and $400 \mathrm{mg} / \mathrm{kg}$ body weight, while the positive control group was treated with diazepam $(1 \mathrm{mg} / \mathrm{kg})$ and control with normal saline water containing $1 \%$ Tween 80 in solution. Thirty minutes later, thiopental sodium (40 $\mathrm{mg} / \mathrm{kg}$ body weight) was administered intraperitoneally to each mouse to induce sleep. The animals were observed for the latent period for the onset time of sleep (i.e. time between thiopental administration and loss of righting reflex) and duration of sleep (i.e. time between the loss and recovery of righting reflex).

Tail suspension test (TST): Tail suspension test is a commonly employed behavioral model for screening antidepressants in mice. ${ }^{25}$ The mice selected for this study were divided into 4 groups having three each and treated with tested 
materaals as per Table IV. Thirty minutes later, they were individually suspended to the edge of a table, $50 \mathrm{~cm}$ above the floor, by adhesive tape placed approximately $1 \mathrm{~cm}$ from the tip of the tail. The total period of immobility was recorded manually for five min. Animal was considered to be immobile when it did not show any body movement, hung passively without any motion. The observer of the immobility of animals was blind to the drug treatments under study.

Forced swim test (FST): It is one the most frequently used behavioral models for evaluating antidepressant-like activity in rodents. ${ }^{25}$ Here, 12 mice were divided into 4 groups having three each and treated with tested materials as per table V. Thirty minutes later, mice were individually forced to swim in open glass chamber $(25 \mathrm{~cm} \times 15$ $\mathrm{cm} \times 25 \mathrm{~cm}$ ) containing fresh water to a height of $15 \mathrm{~cm}$ and maintained at $25 \pm 1{ }^{\circ} \mathrm{C}$. At this height of water, animals were not able to support themselves by touching the bottom or the side walls of the chamber with their hind-paws or tail. Water in the chamber was changed after subjecting each animal to FST. Behavioral responses (immobility, climbing and swimming) were recorded during the $5 \mathrm{~min}$ test session and analyzed. Here, swimming indicates active movements of extremities and circling in the cylinder, climbing indicates active upward directed movements of forelimbs on the container wall and immobility means floating in water without swimming. ${ }^{26}$

Statistical analysis: Values were expressed as mean \pm standard deviation $(\mathrm{n}=3)$. Statistical comparisons were done by using Student's t-test. The $\mathrm{p}<0.05$ was considered as statistically significant.

\section{Result}

Acetic acid-induced writhing method: The writhing number of the treated mice was used to evaluate the peripheral analgesia. The results are given in Table I. The methanolic extract of the tested plant was able to reduce the writhing significantly $(\mathrm{P}<0.05)$ at a dose 200 and 400 $\mathrm{mg} / \mathrm{kg}$ body weight after oral administration in compare to the non-treated mice acetic acidinduced mice.

Tail immersion technique: The thermal stimuli mediated pain caused tail flicking in mice. The tail flicking latency period per minute was a parameter to measure the central pain relieving capacity of the plant. The results are described in Table- 2 . Treatment with 200 and $400 \mathrm{mg} / \mathrm{kg}$ body weight of the plant extract significantly $(\mathrm{P}<0.05)$ protected the animals from the heat-stimulated pain. In this method, the methanol extract showed significant increase of tail flick latency per minute $(\mathrm{P}<0.05)$ after 60 and 90 minutes in both doses.

Table I: Effect of Brassica rapa var. chinensis on acetic acid induced writhing in mice.

\begin{tabular}{|c|c|c|c|c|c|}
\hline \multirow{2}{*}{$\begin{array}{c}\text { Animal } \\
\text { Group }\end{array}$} & \multicolumn{2}{|c|}{$\begin{array}{c}\text { Initial oral } \\
\text { treatment }\end{array}$} & \multirow{2}{*}{$\begin{array}{c}\text { Consequent } \\
\text { intraperitoneal } \\
\text { administration } \\
\text { of } 0.7 \%(\mathrm{v} / \mathrm{v}) \\
\text { acetic } \mathrm{acid} / \mathrm{kg} \\
\text { body weight }\end{array}$} & \multirow{2}{*}{$\begin{array}{l}\text { Writhing } \\
\text { number }\end{array}$} & \multirow{2}{*}{$\begin{array}{c}\% \\
\text { Inhibition }\end{array}$} \\
\hline & Material & Dose & & & \\
\hline Control & $\begin{array}{c}1 \% \\
\text { Tween } \\
80 \text { in } \\
\text { normal } \\
\text { saline }\end{array}$ & $10 \mathrm{ml}$ & $10 \mathrm{ml}$ & $19.33 \pm 1.20$ & -- \\
\hline Standard & $\begin{array}{c}\text { Diclofenac } \\
\text { sodium }\end{array}$ & $1 \mathrm{mg}$ & $10 \mathrm{ml}$ & $4.67 \pm 1.20^{*}$ & 75.84 \\
\hline $\begin{array}{l}\text { Test } \\
\text { group-1 }\end{array}$ & $\begin{array}{c}\text { Methanol } \\
\text { extract }\end{array}$ & $200 \mathrm{mg}$ & $10 \mathrm{ml}$ & $5.67 \pm 2.49 *$ & 70.67 \\
\hline $\begin{array}{l}\text { Test } \\
\text { group-2 }\end{array}$ & $\begin{array}{c}\text { Methanol } \\
\text { extract }\end{array}$ & $400 \mathrm{mg}$ & $10 \mathrm{ml}$ & $3.33 \pm 3.72 *$ & 82.77 \\
\hline
\end{tabular}

Tail immersion technique: The thermal stimuli mediated pain caused tail flicking in mice. The tail flicking latency period per minute was a parameter to measure the central pain relieving capacity of the plant. The results are described in Table-2. Treatment with 200 and $400 \mathrm{mg} / \mathrm{kg}$ body weight of the plant extract significantly $(\mathrm{P}<0.05)$ protected the animals from the heat-stimulated pain. In this method, the methanol extract showed significant increase of tail flick latency per minute $(\mathrm{P}<0.05)$ after 60 and 90 minutes in both doses.

Table II: Effect of Brassica rapa var. chinensis on tail immersion test in mice.

\begin{tabular}{|c|c|c|c|c|c|c|c|}
\hline \multirow{2}{*}{$\begin{array}{c}\text { Animal } \\
\text { Group } \\
\text { (Treatment) }\end{array}$} & \multirow{2}{*}{$\begin{array}{c}\text { Dose } \\
\text { (route) }\end{array}$} & \multicolumn{2}{|c|}{$\begin{array}{c}\text { After } 30 \\
\text { minutes }\end{array}$} & \multicolumn{2}{|c|}{$\begin{array}{l}\text { After } 60 \\
\text { minutes }\end{array}$} & \multicolumn{2}{|c|}{$\begin{array}{l}\text { After } 90 \\
\text { minutes }\end{array}$} \\
\hline & & TFI PM & $\%$ I & FLPM & $\%$ I & LPM & $\%$ I \\
\hline $\begin{array}{c}\text { Control } \\
\text { (1\% Tween } \\
80 \text { in normal } \\
\text { saline) }\end{array}$ & $\begin{array}{r}10 \mathrm{~m} \\
\text { body } \mathrm{v} \\
\text { (or }\end{array}$ & $\begin{array}{c}6.47 \pm \\
1.86\end{array}$ & -- & $\begin{array}{c}6.03 \pm \\
1.02\end{array}$ & -- & $\begin{array}{c}5.97 \pm \\
0.62\end{array}$ & -- \\
\hline $\begin{array}{l}\text { Stand } \\
\text { (Morp }\end{array}$ & $\begin{array}{r}2 \mathrm{mg} / \mathrm{k} \\
\text { we } \\
\text { (subcut }\end{array}$ & $\begin{array}{r}15.10 \\
\pm 1.51\end{array}$ & 133.5 & $\begin{array}{c}15.11 \\
\pm \\
1.51 * *\end{array}$ & 150.3 & $\begin{array}{c}11.43 \\
\pm \\
1.31 *\end{array}$ & 91.6 \\
\hline $\begin{array}{c}\text { Test group-1 } \\
\text { (Methanol } \\
\text { extract) }\end{array}$ & $\begin{array}{r}2001 \\
\text { body } \\
(01\end{array}$ & $\begin{array}{c}8.37 \pm \\
1.53\end{array}$ & 29.38 & $\begin{array}{l}10.57 \\
\pm \\
1.58 *\end{array}$ & 75.19 & $\begin{array}{c}10.79 \\
\pm \\
1.15^{* *}\end{array}$ & 80.9 \\
\hline $\begin{array}{c}\text { Test group-2 } \\
\text { (Methanol } \\
\text { extract) }\end{array}$ & $\begin{array}{l}400 \mathrm{mg} / \mathrm{kg} \\
\text { body weight } \\
\text { (oral) }\end{array}$ & $\begin{array}{c}8.45 \pm \\
0.81\end{array}$ & 30.67 & $\begin{array}{c}11.37 \\
\pm \\
1.43^{* *}\end{array}$ & 90.61 & $\begin{array}{c}12.10 \\
\pm \\
1.74 *\end{array}$ & 100.55 \\
\hline
\end{tabular}

Values are presented as mean \pm standard deviation; $\mathrm{n}=3$; Data were analyzed by student's t-test; Standard and test groups were compared with the vehicle treated group; ${ }^{*} \mathrm{p}<0.05 ;{ }^{*} \mathrm{p}<0.005$; TFLPM - Tail flick latency per minute; $\%$ I - \% inhibition 
Thiopental sodium induced sleeping time test: The time for onset of sleep and duration of sleep were taken as parameters to determine the antidepressant psychostimulant activity. The outcome of the experiment is mentioned in Table III. The methanolic (200 mg/kg body weight) extract produced a significant $(\mathrm{P}<0.005)$ highest increase in the time of onset of sleep as well as reduction of sleep induced by thiopental. However, the extract at $400 \mathrm{mg} / \mathrm{kg}$ body weight intensified these actions significantly.

Tail suspension test (TST): In this test (Table IV), animals treated with two doses of methanol extract (200 and $400 \mathrm{mg} / \mathrm{kg}$ body weight) and standard fluoxetine $(20 \mathrm{mg} / \mathrm{kg}$ body weight $)$ showed significant decrease in their immobility time, in compare to the control group.

Table III: Effects of Brassica rapa var. chinensis on thiopental induced sleeping time in mice

\begin{tabular}{|c|c|c|c|c|c|}
\hline \multirow{2}{*}{$\begin{array}{l}\text { Animal } \\
\text { Group }\end{array}$} & \multicolumn{2}{|c|}{$\begin{array}{c}\text { Initial oral } \\
\text { treatment }\end{array}$} & \multirow{2}{*}{$\begin{array}{c}\text { Consequent } \\
\text { intraperitoneal } \\
\text { administration of } \\
\text { thiopental sodium } / \mathrm{kg} \\
\text { body weight }\end{array}$} & \multirow{2}{*}{$\begin{array}{c}\text { Time of } \\
\text { onset of sleep } \\
\text { (minute) }\end{array}$} & \multirow{2}{*}{$\begin{array}{l}\text { Duration } \\
\text { of } \\
\text { sleeping } \\
\text { time } \\
\text { (minute) }\end{array}$} \\
\hline & Material & $\begin{array}{c}\text { Per kg } \\
\text { body } \\
\text { weight }\end{array}$ & & & \\
\hline Control & $\begin{array}{l}1 \% \text { Tween } \\
80 \text { in } \\
\text { normal } \\
\text { saline }\end{array}$ & $10 \mathrm{ml}$ & $40 \mathrm{mg}$ & $17.33 \pm 2.52$ & $108 \pm 8.89$ \\
\hline Standard & Diazepam & $1 \mathrm{mg}$ & $40 \mathrm{mg}$ & $10.67 \pm 2.52 *$ & $198.33 \pm 15$ \\
\hline $\begin{array}{l}\text { Test } \\
\text { group-1 }\end{array}$ & $\begin{array}{l}\text { Methanol } \\
\text { extract }\end{array}$ & $200 \mathrm{mg}$ & $40 \mathrm{mg}$ & $92 \pm 24.42 * *$ & $41.67 \pm 11.50$ \\
\hline $\begin{array}{l}\text { Test } \\
\text { group-2 }\end{array}$ & $\begin{array}{l}\text { Methanol } \\
\text { extract }\end{array}$ & $400 \mathrm{mg}$ & $40 \mathrm{mg}$ & $\begin{array}{l}103.23 \pm \\
15.57 * *\end{array}$ & $25 \pm 9.54$ \\
\hline
\end{tabular}

Forced swim test (FST): The possible antidepressant effect of B. rapa was studied in the forced swimming test. In this test (Table V), mice treated with two doses of methanol extract (200 and $400 \mathrm{mg} / \mathrm{kg}$ body weight) and standard fluoxetine $(20 \mathrm{mg} / \mathrm{kg}$ body weight $)$ showed significant effect on their immobility, swimming and climbing in compare to the control group.

Table IV: Effect of Brassica rapa var. chinensis on tail suspension test in mice

\begin{tabular}{|c|c|c|c|}
\hline \multirow{2}{*}{$\begin{array}{l}\text { Animal } \\
\text { Group }\end{array}$} & \multicolumn{2}{|c|}{ Oral treatment } & \multirow{2}{*}{$\begin{array}{c}\text { Tail suspension } \\
\text { test immobility } \\
\text { (second) }\end{array}$} \\
\hline & Material & $\begin{array}{c}\text { Per kg body } \\
\text { weight }\end{array}$ & \\
\hline Control & $\begin{array}{c}1 \% \text { Tween } \\
80 \text { in normal } \\
\text { saline }\end{array}$ & $10 \mathrm{ml}$ & $52.66 \pm 2.56$ \\
\hline Standard & Fluoxetine & $20 \mathrm{mg}$ & $19.33 \pm 3.29 * *$ \\
\hline $\begin{array}{c}\text { Test } \\
\text { group-1 }\end{array}$ & $\begin{array}{c}\text { Methanol } \\
\text { extract }\end{array}$ & $200 \mathrm{mg}$ & $40.33 \pm 2.56^{*}$ \\
\hline $\begin{array}{c}\text { Test } \\
\text { group-2 }\end{array}$ & $\begin{array}{c}\text { Methanol } \\
\text { extract }\end{array}$ & $400 \mathrm{mg}$ & $34.66 \pm 3.23 * *$ \\
\hline
\end{tabular}

Values are presented as mean \pm standard deviation; $\mathrm{n}=3$; Data were analyzed by student's t-test; Standard and test groups were compared with the vehicle treated group; ${ }^{*} \mathrm{p}<0.05 ;{ }^{*} \mathrm{p}<0.005$
Table V: Effect of Brassica rapa var. chinensis on forced swim test in mice

\begin{tabular}{|c|c|c|c|c|c|}
\hline \multirow{2}{*}{$\begin{array}{l}\text { Animal } \\
\text { Group }\end{array}$} & \multicolumn{2}{|c|}{ Oral treatment } & \multirow{2}{*}{$\begin{array}{c}\text { Immobility } \\
\text { (second) }\end{array}$} & \multirow{2}{*}{$\begin{array}{l}\text { Swimming } \\
\text { (second) }\end{array}$} & \multirow{2}{*}{$\begin{array}{l}\text { Climbing } \\
\text { (second) }\end{array}$} \\
\hline & Material & $\begin{array}{c}\text { Per kg } \\
\text { body } \\
\text { weight }\end{array}$ & & & \\
\hline Control & $\begin{array}{c}1 \% \text { Tween } \\
80 \text { in } \\
\text { normal } \\
\text { saline }\end{array}$ & $10 \mathrm{ml}$ & $122.63 \pm 3.12$ & $\begin{array}{c}96.36 \pm \\
3.23\end{array}$ & $\begin{array}{c}80.21 \pm \\
3.85\end{array}$ \\
\hline Standard & Fluoxetine & $20 \mathrm{mg}$ & $\begin{array}{l}50.25 \pm \\
2.39 * *\end{array}$ & $\begin{array}{c}135.23 \pm \\
2.11 * *\end{array}$ & $\begin{array}{c}113.65 \pm \\
2.58 * *\end{array}$ \\
\hline $\begin{array}{c}\text { Test } \\
\text { group-1 }\end{array}$ & $\begin{array}{c}\text { Methanol } \\
\text { extract }\end{array}$ & $200 \mathrm{mg}$ & $\begin{array}{c}103.33 \pm \\
3.10^{*}\end{array}$ & $\begin{array}{c}105.33 \pm \\
2.74 *\end{array}$ & $\begin{array}{c}90.54 \pm \\
2.77 *\end{array}$ \\
\hline $\begin{array}{c}\text { Test } \\
\text { group-2 }\end{array}$ & $\begin{array}{c}\text { Methanol } \\
\text { extract }\end{array}$ & $400 \mathrm{mg}$ & $\begin{array}{l}89.65 \pm \\
2.65 * *\end{array}$ & $\begin{array}{c}115.32 \pm \\
1.56^{* *}\end{array}$ & $\begin{array}{c}94.21 \pm \\
3.33 * *\end{array}$ \\
\hline
\end{tabular}

\section{Discussion}

The experimental data of analgesic and antidepressant assay of $B$. rapa subspecies chinensis have been summarized in Tables I to V. It is known that prostaglandin is responsible for pain production. So, there is a possibility that the analgesic activity of the plant might be related with the inhibition of the prostaglandin production. Intraperitoneal injection of acetic acid produces high level of prostaglandin $\mathrm{E}_{2}$ and prostaglandin $\mathrm{F}_{2 \alpha}$ within $30 \mathrm{~min}$ of injection. Besides, it has the ability to produce many sympathetic neuronal mediators. Therefore, it can be assumed that this plant extract might either inhibit the cyclooxygenase (COX) enzymes to block the biosynthetic pathway of prostaglandin production or inhibit the binding of prostanoids to their receptors. The extract might also be responsible for inhibiting the production of neuronal mediators. The used standard drug diclofenac sodium, a potent COX inhibitor, was successful for reducing the pain indicating the correlation of the prostaglandin inhibition mediated analgesic action at least. ${ }^{27-29} \mathrm{~A}$ delta fibres and $\mathrm{C}$ fibres sensory neurons are available in skin linked for thermal pain generation. In addition, ion channels in the skin respond to temperature, which let in both calcium ions and sodium ions. So, the action potential is generated in the nerve and sends message to the spinal cord and brain to recognize the pain. The tested plant in the tail immersion assay might have the ability to alter the action potential and signal transmission to counteract the pain produced by heat. ${ }^{30}$

For evaluating the primary antidepressant psychostimulant activity, thiopental sodium induced sleeping time test was utilized. The delay 
in the time of onset of sleep and the reduction in the sleep time than control group indicate a central nervous system stimulant activity of the methanolic extract. ${ }^{31-33}$

Based on depressive episodes and stress, the two most widely used animal model tests for antidepressant screening are the forced swimming test (FST) and tail suspension test (TST). ${ }^{25,26}$ In TST, immobility mimics a state of depression which might be reduced by several antidepressive agents. Similarly, in the FST, mice are forced to swim in restricted space, which might induce a state of behavioral despair in animals reflecting a depression. The administration of the methanol extract produced a diminution of immobility time of mice exposed to the both forced swimming and tail suspension tests. In addition, the forced swim test showed the increased active behavior like swimming and climbing. It has been established that the shortening of immobility time in the forced swimming and the tail suspension tests depends mainly on the enhancement of central 5HT (hydroxytryptamine)and catecholamine neurotransmission. Taken together, the plant showed antidepressant-like activity without affecting locomotor activity. ${ }^{25,26,34,35}$

The secondary metabolites produced in this plant might have a greater role for the analgesic and antidepressant activities. It has already been reported that $B$. rapa subspecies chinensis produces lot of kaemferol and isorhamnetin type flavonoids. ${ }^{11}$ These flavonoids have the potentials to act as both analgesic ${ }^{36,37}$ and antidepressant agents. ${ }^{38,39}$ These might be considered as one of the reasons to justify the analgesic and antidepressant actions of this herb.

Conclusion: The methanolic extract of $B$. rapa subsp. chinensis exhibited analgesic and antidepressant activities in mice model. Further comprehensive investigations are required to explore the detail mechanisms behind these bioactivities and isolate the bioactive molecules from this plant.

\section{References}

1. Benites J, Gutierrez E, Lopez J, Rojas M, Rojo L, Costa Mdo C, Vinardell MP, Calderon PB. Evaluation of analgesic activities of tremetone derivatives isolated from the Chilean altiplano medicine Parastrephia lepidophylla. Nat Prod Commun 2012; 7: 611-4.

2. Christen P, Cuendet M. Plants as a source of therapeutic and health products. Chimia (Aarau) 2012;66: 320-3.

3. Hung HY, Qian K, Morris-Natschke SL, Hsu CS, Lee $\mathrm{KH}$. Recent discovery of plant-derived anti-diabetic natural products. Nat Prod Rep 2012; 29: 580-606.

4. Kasper S, Schulz V. St. Johns wort extract as plant antidepressant. Praxis (Bern 1994) 2000; 89: 216977.

5. Su S, Hua Y, Wang Y, Gu W, Zhou W, Duan JA, Jiang H, Chen T, Tang Y. Evaluation of the antiinflammatory and analgesic properties of individual and combined extracts from Commiphora myrrha, and Boswellia carterii. J Ethnopharmacol 2012; 139: 649-56.

6. Xiong Z, Jiang B, Wu PF, Tian J, Shi LL, Gu J, Hu ZL, Fu H, Wang F, Chen JG. Antidepressant effects of a plant-derived flavonoid baicalein involving extracellular signal-regulated kinases cascade. Biol Pharm Bull 2011; 34: 253-9.

7. Yu CH, Tang WZ, Peng C, Sun T, Liu B, Li M, Xie XF, Zhang H. Diuretic, anti-inflammatory, and analgesic activities of the ethanol extract from Cynoglossum lanceolatum. J Ethnopharmacol 2012; 139: 149-54.

8. Dominguez-Perles R, Mena P, Garcia-Viguera C, Moreno DA. Brassica foods as a dietary source of vitamin C: A review. Crit Rev Food Sci Nutr 2014; 54: 1076-91.

9. Siddiqui MM, Abbasi BH, Ahmad N, Ali M, Mahmood T. Toxic effects of heavy metals $(\mathrm{Cd}, \mathrm{Cr}$ and $\mathrm{Pb}$ ) on seed germination and growth and DPPHscavenging activity in Brassica rapa var. turnip. Toxicol Ind Health 2014; 30: 238-49.

10. Fernandes F, Valentão P, Sousa C, Pereira JA, Seabra RM, Andrade PB. Chemical and antioxidative assessment of dietary turnip (Brassica rapa var. rapa L.). Food Chem 2007; 105: 1003-10.

11. Mucha-Pelzer T, Mewis I, Ulrichs C. Response of glucosinolate and flavonoid contents and composition of Brassica rapa ssp. chinensis (L.) Hanelt to silica formulations used as insecticides. J Agric Food Chem 2010; 58: 12473-80. 
12. Romani A, Vignolini P, Isolani L, Ieri F, Heimler D. HPLC-DAD/MS characterization of flavonoids and hydroxycinnamic derivatives in turnip tops (Brassica rapa L. Subsp. sylvestris L.). J Agric Food Chem 2006; 54: 1342-6.

13. Tenore GC, Troisi J, Di Fiore R, Basile A, Novellino E. Chemical composition, antioxidant and antimicrobial properties of Rapa Catozza Napoletana (Brassica rapa L. var. rapa DC.) seed meal, a promising protein source of Campania region (southern Italy) horticultural germplasm. J Sci Food Agric 2012; 92: 1716-24.

14. Ara K, Rahman AH, Hasan CM, Iskander MN, Asakawa Y, Quang DN, Rashid MA. Macrocyclic diarylheptanoids from Garuga pinnata. Phytochemistry 2006; 67: 2659-62.

15. Begum R, Rahman MS, Chowdhury S, Rahman MM, Gibbons S, Rashid MA. A new 7-oxygenated coumarin from Clausena suffruticosa. Fitoterapia 2010; 81: 656-8

16. Islam MR, Uddin MZ, Rahman MS, Tutul E, Rahman MZ, Hassan MA, Faiz MA, Hossain M, Hussain M, Rashid MA. Ethnobotanical, phytochemical and toxicological studies of Xanthium strumarium L. Bangladesh Med Res Counc Bull 2009; 35: 84-90.

17. Jahan I, Rahman MS, Rahman MZ, Kaisar MA, Islam MS, Wahab A, Rashid MA. Chemical and biological investigations of Delonix regia (Bojer ex Hook.) Raf. Acta Pharm 2010; 60: 207-15.

18. Rahman MS, Rahman MZ, Begum B, Chowdhury R, Islam SN, Rashid MA. Antidiabetic principle from Eclipta prostrata. Latin Am J Pharm 2011; 30: 165660.

19. Amabeoku GJ, Kabatende J. Antinociceptive and anti-Inflammatory activities of leaf methanol extract of Cotyledon orbiculata L. (Crassulaceae). Adv Pharmacol Sci 2012; 2012: 862625.

20. Chen J, Wang X, Qu YG, Chen ZP, Cai H, Liu X, Xu F, Lu TL, Cai BC. Analgesic and anti-inflammatory activity and pharmacokinetics of alkaloids from seeds of Strychnos nux-vomica after transdermal administration: Effect of changes in alkaloid composition. J Ethnopharmacol 2012; 139: 181-8.

21. Liao CR, Chang YS, Peng WH, Lai SC, Ho YL. Analgesic and anti-inflammatory activities of the methanol extract of Elaeagnus oldhamii Maxim. in mice. Am J Chin Med 2012; 40: 581-97.

22. Aydin S, Demir T, Ozturk Y, Baser KH. Analgesic activity of Nepeta italica L. Phytother Res 1999; 13: 20-3.

23. Kaushik D, Kumar A, Kaushik P, Rana AC. Analgesic and anti-Inflammatory activity of Pinus roxburghii Sarg. Adv Pharmacol Sci 2012; 2012: 245431 .
24. Ferrini R, Miragoli G, Taccardi B. Neuropharmacological studies on SB 5833, a new psychotherapeutic agent of the benzodiazepine class. Arzneimittelforschung 1974; 24: 2029-32.

25. Santosh P, Venugopl R, Nilakash A S, Kunjbihari S, Dr. Mangala L. Antidepressant activity of methanolic extract of Passiflora foetida leaves in mice. Int $\mathbf{J}$ Pharm Pharm Sci 2011; 3: 112-5.

26. Ravindra C. Sutar RD, Kasture SB, Kalaichelvan VK. Evaluation of antidepressant activity of leaf extracts of Holoptelea integrifolia (Roxb) Planch in experimental animals. Int J Pharm Pharm Sci 2014; 6: $150-53$.

27. Deraedt R, Jouquey S, Delevallee F, Flahaut M. Release of prostaglandins $\mathrm{E}$ and $\mathrm{F}$ in an algogenic reaction and its inhibition. Eur J Pharmacol 1980; 61: 17-24.

28. Duarte ID, Nakamura M, Ferreira SH. Participation of the sympathetic system in acetic acid-induced writhing in mice. Braz J Med Biol Res 1988; 21: 3413.

29. Sikder MAA, Rashid RB, Islam F, Hossian AKMN, Siddique AB, Kabir S, Haque MR, Rahman MS, Rashid MA. Screening of ten medicinal plants of Bangladesh for analgesic activity on Swiss-albino mice. Orient Pharm Exp Med 2013; 13: 327-32.

30. Harris NC, Ryall RW. Mustard oil excites but does not inhibit nociceptive dorsal horn neurones in the rat: a presumed effect on A-delta fibres. $\mathrm{Br} \mathrm{J}$ Pharmacol 1988; 94: 180-4.

31. Alnamer R, Alaoui K, Bouidida EH, Benjouad A, Cherrah Y, Psychostimulant activity of Rosmarinus officinalis essential oils. J Nat Prod 2012; 5: 83-92.

32. Alnamer R, Alaoui K, Bouidida EH, Benjouad A, Cherrah Y. Psychostimulants activity of Rosmarinus officinalis L methanolic and aqueous Extracts. J Med Plants Res 2012; 6: 1860-5.

33. Kaur K, Kumar D, Kumar S. Screening of neuropharmacological activities of Calotropis gigantean roots. J Pharm Chem Biol Sci 2014; 2: 186-96.

34. Lee M, Kim YH, Park W, Ahn WG, Park OK, Kwon S, Morita K, Shim I, Her S. Novel antidepressant-like activity of caffeic acid phenethyl ester is mediated by enhanced glucocorticoid receptor function in the hippocampus. J Evid Based Complementary Altern Med 2014; vol. 2014: article ID 646039, doi:10.1155/2014/646039.

35. Borsini F, Meli A. Is the forced swimming test a suitable model for revealing antidepressant activity? Psychopharmacology (Berl.) 1988; 94: 147-60. 
36. Maleki-Dizaji N, Fathiazad F, Garjani A. Antinociceptive properties of extracts and two flavonoids isolated from leaves of Danae racemosa. Arch Pharm Res 2007; 30: 1536-42.

37. Aquino AB, Cavalcante-Silva LH, Matta CBB, Epifânio WA, Aquino PG, Santana AE, AlexandreMoreira MS, de Araújo-Júnior JX. The antinociceptive and anti-inflammatory activities of aspidosperma tomentosum (Apocynaceae). Scientific World J 2013; 2013: 218627 , doi:10.1155/2013/21862.
38. Park S-H, Sim Y-B, Han P-L, Lee J-K, Suh H-W. Antidepressant-like effect of Kaempferol and Quercitirin, isolated from Opuntia ficus-indica var. saboten. Exp Neurobiol 2010; 19: 30-38.

39. Gong JY, Huang J, Ge Q, Chen F, Zhang Y. Advanced research on the antidepressant effect of flavonoids. Curr Opin Complement Alternat Med 2014; 1: e00011. doi: 10.7178/cocam.00011 